\title{
Lessons from the Japanese ninja: on achieving a higher trade equilibrium under anarchy and private constitutions
}

\author{
Vladimir V. Maltsev ${ }^{1,2}$ (])
}

Accepted: 1 December 2021 / Published online: 16 December 2021

(c) The Author(s) 2021

\begin{abstract}
This paper investigates the possibility of anarchy achieving a high trade equilibrium via the example of ninja communities in Japan. Initially, ninjas in the mountainous regions of Iga and Kōka were stateless, constantly feuded, and had few opportunities for exchange. With the advent of civil war in the sixteenth century, ninjas' economic conditions changed. The mercenary market significantly expanded and presented great profit opportunities for the ninjas. However, instead of creating a formal government to move to a higher trade equilibrium, the ninjas resorted to forming voluntary confederations held together by private constitutions. I argue that this development was possible because the institutional environment of the Sengoku period enabled a framework of self-governing institutions and principles. The ninjas were able to build on this framework with very low organizational costs. As a result, the ninjas were able to reap large economic gains on the mercenary market while remaining stateless-a seemingly paradoxical development that goes against the standard dichotomy of "states and thick markets" versus "anarchy and thin markets."
\end{abstract}

Keywords Ninjas $\cdot$ Anarchy $\cdot$ Self-governance $\cdot$ Constitutions $\cdot$ Japan

JEL Classification N45 $\cdot$ P48

\section{A stealthy introduction}

The medieval to early modern period in Japan was characterized by "centuries of intrigue, murder, predation, and war," (Adolphson \& Ramseyer, 2009: 660) and the fifteenth century marked the beginning of a particularly tumultuous period in the country's history. The establishment of the Ashikaga shogunate led to several

Vladimir V. Maltsev

vmaltsev92@gmail.com; vladimir.maltsev@kcl.ac.uk

1 Department of Economic Theory, Financial University Under the Government of the Russian Federation, Moscow, Russia

2 Centre for the Study of Governance and Society, King's College, London, UK 
uprisings as tensions among lords, samurai, and peasants kept mounting. Japan was eventually plunged into a state of political disarray after the shogunate- the centralized feudal military government-lost almost all its influence after a civil conflict called the Ōnin War, which lasted from 1467 to $1477 .{ }^{1}$ Finally, in the late fifteenth century, Japan entered the Sengoku period, also known as the Age of the Country at War.

The resulting power vacuum from the war lasted from 1480 to 1600 (Turnbull, 2017: 2). Property rights became insecure, markets thinned, and the provision of public goods significantly weakened. Bandits proliferated, and the feudal lords (the daimyo) struggled for control and power. The daimyo often abused the peasant populations by extorting exorbitant taxes to fuel their own political ambitions, which only sparked new conflicts. The daimyo's samurai razed crops, stole food, and destroyed houses amid numerous battles (Man, 2013: 73); meanwhile, "villages withheld taxes, deserted their fields, wrested control of local markets away from the samurai, and complained to the daimyo of samurai abuse" (Birt, 1985: 381).

However, in some regions of Japan, the economy grew, despite these circumstances. In some regions, this development was secured by Japanese temples and monasteries, which offered protection, dispute adjudication, and contract enforcement within their jurisdictions amid the chaos of the Sengoku era (Adolphson \& Ramseyer, 2009). The mountainous regions of Iga and $\mathrm{Kōka}^{2}$ regions to the southeast of Kyoto, however, saw their relevant market thicken based on high demand for ninjas, also known as shinobi or shadow warriors. The phenomenon of the ninja emerged through escape and defeat, as many individuals preferred to flee from the gruesome civil conflicts and the predatory Japanese feudal lords. Mountainous areas such as Iga and Kōka became places of refuge for fleeing soldiers, peasants, and individuals from other walks of life. Survival in the mountains required skill, and from this need, the art of the ninja, or ninjutsu, was born. Unlike the pop cultural image of ninja as master assassins, clad in black garments and utilizing a wide range of weapons from throwing stars to smoke bombs, the actual ninjas are better classified as simple intelligence gatherers and spies (Turnbull, 2017: 4). Indeed, early manuscripts detailing the shinobi arts contain no information on martial arts or assassination methods, instead writing extensively on survival techniques, simple disguises and various esoteric rituals (Cummins \& Minami, 2017).

The Sengoku era created a high demand for practitioners of ninjutsu (Zoughari, 2010: 23), as the warfare between the daimyo frequently involved intelligence gathering, infiltration, and spying (Fujiki, 2005; Sugiyama, 1980; Yamaguchi, 1962). ${ }^{3}$ For Iga and Kōka, the geographic position was also crucial, as both regions were located some fifty kilometers southeast of Kyoto, the country's capital, and were

\footnotetext{
1 The position of the shogun remained intact. However, it became devoid of significant political meaning because the shogun failed to consolidate power.

2 Sometimes also written as Koga or Kōga.

${ }^{3}$ However, the expertise of the ninjas in combat was at times also sought after. The Chronicle of Oda Nobunaga, for instance, mentions how the archers of Iga fought in Northern Ōmi province (Elisonas \& Lamers, 2011: 207).
} 
shielded by high-altitude terrain. Iga was located in a basin, surrounded by mountains, while Koga's landscape was one of steep hills descending to Lake Biwa (Soyuri, 2010: 110). This central, but well-protected location meant that the ninjas could be summoned very quickly to assist in fighting, but at the same time, remain largely unaffected by the ongoing warfare.

Before the Sengoku period, the market in the ninja heartland was thin-focused on mostly agriculture - and the regions were "forever feuding" with "small-scale, low-level" fighting (Man, 2013: 80; Soyuri, 2010: 119). Both Iga and Kōka lacked centralized authority, as the net benefits of introducing developed governance structures to the regions were smaller than the costs of enduring the small-scale infighting. The regions were under the influence, but not control, of the great monasteries of Nara prefecture such as Tōdaiji (Tobe, 1996). Man (2013: 80) claims that "Iga, in particular, had no military governor for many centuries" and "never paid a land tax either to the shogun or to the emperor."

As the market around Iga and Kōka thickened, the logic of public choice would predict the establishment of a formal government for the ninjas. The creation of the protective and productive state (Buchanan, 1975; Buchanan \& Tullock, 1962) in Iga and Kōka would keep violence in check and allow for better provision of non-protection-related public goods. In turn, this would enable the ninjas to shift to a higher trade equilibrium. However, the regions remained anarchic yet still attained a higher trade equilibrium.

The main contribution of this paper is to explain a possible logic behind this seemingly paradoxical development of anarchy paired with thick markets. My argument is that instead of integrating into the state to move to a thick market, anarchic communities may simply choose more complex anarchic arrangements to fulfill that objective. The problem becomes trivial if the institutional environment around a particular group is particularly conducive to private governance, supplied with an existing institutional "skeleton" that can be easily imported and modified.

From the perspective of constitutional economics, the case of the ninjas is particularly interesting, as the shadow warriors managed to move to a higher level of trade under anarchy because of the widespread institution of $i k k i$-private confederations whose governance was secured with private constitutions. The ninjas were able to copy this popular, malleable system of governance at virtually no cost and shape their own constitution to prosper on a thick mercenary market.

\section{The invisible theory}

The dichotomy between state and anarchy and their respective levels of trade has been frequently noted. Gunning (1972) and Greif (2005) claim that complex trade arrangements require external enforcement by a formal government. Similarly, Buchanan (1972) expresses his doubts that individuals will not act opportunistically in the absence of a formal state. However, some scholars (Moselle \& Polak, 2001; Powell \& Coyne 2003) state that anarchy may be preferable to a state when the latter is too costly to organize, predatory, or inefficient, though anarchy may entail a lower level of trade. 
The choice between introducing states and staying under anarchy is clearly explicated in a simple formal model by Leeson (2009). Leeson denotes $H$ as the "the sum of the payoffs to each individual of trade when government is present," and $L$ as the "sum of the individual payoffs of the relatively lower level of trade when government is absent." The cost of government is denoted by $G$ and depends on the costs of organizing, enforcing rules, and providing public goods as well as the costs of possible abuses of political power. If the condition $H-L>G$ holds, then introducing the state is feasible. Otherwise, anarchy is the preferable mode of social organization.

While the logic is reasonable, it nevertheless omits the possibility that anarchy might secure a higher level of trade. Let us then build on Leeson's model and theoretically allow for such a possibility by making a distinction between higher trade equilibria under anarchy and under the state. I denote the former as $H_{a}$ and the latter as $H_{g}$.

Further, in his model, Leeson implicitly assumes that the organizational costs of achieving $L$ are zero. However, we can no longer assume those costs to be zero when anarchy moves to $H_{a}$ and thus requires more complex organizational solutions. To account for these costs, I introduce $A$, the sum of the costs of organizing, enforcing rules, and providing public goods under more complex anarchy. To be a feasible option for a given group, $H_{a}-L>A$ must hold.

Introducing the new variables creates a system of inequalities. Depending on the placement of inequality signs, we get different outcomes. Let us consider the four cases one by one.

(1) If $H_{a}-L>A$ while $H_{g}-L<G$, then the organizational costs of a higher trade equilibrium under anarchy are less than the benefits of moving to that equilibrium. At the same time, the costs of formal government exceed the difference between the low level of trade under anarchy and the higher level of trade under the state. This means that anarchy allows for an efficient movement to a higher trade equilibrium.

(2) If $H_{a}-L<A$ while $H_{g}-L>G$, then introducing government is the preferred option. In this case, the group might not have the institutional capacity for an efficient movement to a more advanced form of anarchy.

(3) If $H_{a}-L<A$ while $H_{g}-L<G$, then a group will remain under anarchy with a low level of trade. In such a situation, perhaps, both options for introducing more complex organizational systems lie outside the existing economic constraints.

(4) If $H_{a}-L>A$ while $H_{g}-L>G$, then the most efficient system will be determined by whether $H_{a}-L>H_{g}-L$ or $H_{a}-L<H_{g}-\mathrm{L}$. In the former case, the benefits of moving to an advanced form of anarchy are greater than those from forming a state; in the latter, the creation of the state offers more benefits.

But what enables anarchy to move to $H_{a}$ while keeping $A$ low? A hint is contained in Friedman's (1989) concept of alternative governance institutions. As these institutions accumulate, they create a "skeleton" of anarchy within a given society - an existing structure of institutions that groups may build upon. If this 
skeleton is malleable and easily copyable, then a given group may easily import these institutions and adapt them for its own purposes. As shown in the next section, the institutional environment of Japan in the Sengoku period was particularly favorable for such developments, and we can assess which of the four above cases characterizes the ninjas.

\section{The visible evidence}

First, let us untangle why the formation of a state was cost-prohibitive for the ninjas. Feudal relations in Japan developed much as in the "stationary bandit" model (McGuire \& Olson, 1996), as the daimyo's samurai "were commonly involved in looting and thuggery" and had "minimal respect" for laws and the lords themselves often engaged in "extortion and rent-seeking" (Soyuri, 2010: 115). This implies that the cost of government $G$ was often too steep for many social groups in Sengoku Japan. And while the presence of the state at times helped maintain markets and allowed for a transition to $H_{g}$ (Birt, 1985: 386), the gap between $H_{g}$ and $L$ often did not exceed $G$. Villagers frequently complained about samurai extortion (Birt, 1985: 381 ), high tax rates, and predation, all of which frequently caused peasant communities to arm "themselves with simple weapons and guerrilla methods to prevent the trend towards territorial consolidation and centralized taxation" (Ferejohn \& Rosenbluth, 2010: 1). Such a high $G$ may explain the choice of Iga and Kōka to remain stateless during the Sengoku period.

At the same time, the series of conflicts mentioned above allowed the mountainous regions to become home to individuals whose services would be in high demand during that period (Zoughari, 2010: 43, 50). Numerous wars caused warriors to desert and escape to Iga and Kōka. For instance, a lengthy war (Nambokuchō) between the Court of the North, controlled by Ashikaga Takauji in Kyoto and the Court of the South, controlled by Emperor Go-Daigo in Yoshino, which lasted from 1336 to 1392, saw most of its battles unfold close to Iga and Kōka, which led to a great influx of deserters to these regions (Zoughari, 2010: 41). Also of great importance was the frequent presence of the mountain monks-the yamabushi. Practicing ascetism in the mountains to achieve spiritual purity, the monks had to survive in the harsh wilderness, and they imparted to the locals their knowledge of how to survive (Soyuri, 2010: 119). These factors influenced the rise of the ninjas, and during the Sengoku period, the ninjas of Iga and Kōka were in high demand by the warring Japanese daimyo.

Historical evidence shows that the ninjas were able to capitalize on this high demand and did not remain in a state of conflict-ridden anarchy in a low trade equilibrium. On the contrary, thirty-seven areas of Japan purchased the services of the shadow warriors from Iga and Kōka (Man, 2013: 123). The chronicles of Japanese monasteries shed light on some of the tasks that the ninjas performed outside of their heartland. The activities of mercenaries from Iga and Kōka began as early as 1482 . The chronicles mention their participation in the defense of a castle in Yamato province in 1485 and in a siege of the Rokkaku castle in Ömi province, which earned them "considerable recognition" (Sugiyama, 1980). Reports of the ninjas' activities 
are not overly detailed, apart from a mention of how they "went freely into enemy castles in secret." In 1541, Iga ninjas were employed by Miyoshi Chōkei to assist in the siege of Kasagi Castle in Yamashiro province by engaging in arson and other disruptive activities (Zoughari, 2010: 43). The year 1556 marked another ninja raid, in which eleven men from Iga attacked the Takada castle in Yamato and helped to set it on fire (Turnbull, 2017: 40). In 1561, daimyo Asai Nagamasa retook the castle of Futō, which ninjas from Iga were hired to burn down (Miura, 1966: 395-98). Ninjas from Kōka worked with the future shogun Tokugawa Ieyasu in 1562 to take hostages for Ieyasu from the Kaminogō Castle (Yamaguchi, 1962: 24-26). Ninjas in 1580 "crossed the wet moat" of Sakaibe Castle in Uga district and entered it"an action without parallel" (Turnbull, 2017: 41). In 1581, right before the invasion of Iga by Nobunaga, ninjas were sent on an intelligence-gathering mission, holding hostages for ransom to achieve their goal (Fujiki, 2005: 32-34).

As the ninjas fulfilled their numerous contracts across Japan, their newly acquired wealth trickled into Iga and Kōka until the end of the sixteenth century. This is evidenced by a booming construction market, with Kōka alone building no fewer than 230 new fortification works, from hilltop castles to smaller forts (Soyuri, 2010: 113; Turnbull, 2014: 16). Some warrior families became so wealthy that they could provide shelter to the shogun Ashikaga Yoshiaki in 1565 (Yūki, 1988: 119). Furthermore, Oda Nobukatsu - the son of Oda Nobunaga, one of the most powerful daimyo of the Sengoku period, received a complaint about Iga and how individuals in the region "were living in luxurious excess and were not governed by the dark truths of Heaven" (Turnbull, 2017: 65; Tobe, 1996: 51-53). Iga and Kōka also featured a growing number of relay stations that allowed for a higher level of trade and communication (Man, 2013: 88-89). But what allowed the ninjas to transition to $H_{a}$ ?

The main factor was the institutional environment in the country. Although some individuals continued to serve their daimyo, the prevalence of feudal predation created demand for alternative, private means of governance. Adolphson and Ramseyer (2009: 661) note that "medieval Japan maintained a market in private governments." While "prominent among the competitors in this market for basic "governmental" services were the temples and monasteries of the Buddhist faith" (Adolphson \& Ramseyer 2009: 661), there was another source of private governance-namely, self-governing leagues called $i k k i$ or sokoku $i k k i$, based on egalitarian principles and governed by private constitutions (Turnbull, 2014: 15). Oda Nobunaga denounced the $i k k i$ : "Those that ply this outrageous trade do not make any distinction between the high and low, rich or poor classes. This attitude is a mystery to me; they disparage the hierarchy and do not have any respect for the warriors of high rank" (Sugiyama, 1974: 262).

The $i k k i$ were created as alliances of villages or warrior families. For instance, in the Oyamoto region in 1494, 350 individuals created a confederation; they expressed their explicit and voluntary consent by signing a five-article constitution. Later, the constitutional arrangement was expanded with the explicit consent of forty-six warrior families who wanted to join the agreement. The voluntary character of the $i k k i$ formations is also highlighted by the ability of individuals to freely exit the confederacy: "Sometimes the warriors might abandon the community and instead join the 
vassal organizations... when it served their material interests" (Souyri, 2010: 117). This freedom of exit and entry allows us to classify the $i k k i$ as private governance arrangements akin to clubs. According to Leeson (2014: 6), it is precisely the voluntary, explicit consent of such arrangements that helps distinguish a government from self-governance.

The ikki formation in Oyamoto created a skeleton of alternative institutions in Japan and allowed the ninjas to quickly establish their own confederation by copying the basic principles embodied in other $i k k i$. This explains the ability of the ninjas to achieve $H_{a}$ and to keep $A$ low: the institutional solution to the problem of weak private governance was already present in the country, and the shadow warriors had to simply copy and tweak it for their own purposes. In terms of the model outlined in Sect. 2, the case of the ninjas fits the first case, in which $H_{a}-L>A$ while $H_{g}-L<G$.

The Iga $i k k i$ grew to be one of the largest in Japan, consisting of sixty-six warrior families and bolstering its ranks up until 1581. Oda Nobunaga confirmed this trend in one of his recollections: "The number of rebels in Iga increases daily" (Sugiyama, 1974: 262). ${ }^{4}$ The Iga $i k k i$ had a very detailed constitution that played a crucial role in the confederation's private governance and ensured its survival for almost a century. The document survives to this day, and Soyuri (2010: 114) claims that "the particular social system it lays out was created... around the beginning of the sixteenth century, almost at the same time as the neighboring league of the inhabitants of Oyamoto." Turnbull (2017: 47) characterizes the presence of such a detailed constitution in Iga as a sign of one of the "better-organised ikki". The translated text of the constitution is provided in appendix 1.

We can see how the constitution assisted the ninja in achieving $H_{a}$. First, the document delineates the protective function of the Iga ikki. This is evidenced by its article 9, which bans violent encroachments within the confederacy's territory, and articles 1,2, and 3, which secure the provision of defense against aggression by outsiders. Second, the document also demonstrates the productive character of the ikki, as the ikki provided its members with important public goods, such as the system of relay stations (an important infrastructure project) and the war fund, as seen in article 8 . The institutional environment of the Sengoku era and the voluntary nature of the $i k k i$ also created a Tiebout (1956) competition in governance, which constrained potential abuses within the confederacies. The threat of losing all the ikki members because of misconduct and arbitrary changes in the rules bolstered the effectiveness of the ninjas' private governance, similarly to private clubs (Leeson, 2011: 303-4).

The constitution created common knowledge and common expectations about how individuals were supposed to behave. This enhanced its external enforcement, as observed in article 9 . As seen in article 8, the ability to exclude individuals from contractual benefits and access to public goods also created incentives for members to comply with the established rules. Of no less importance was the mountainous

\footnotetext{
${ }^{4}$ Unfortunately, no historical records remain regarding the population size of the Iga $i k k i$, as many historical manuscripts and ledgers were destroyed during Nobunaga's conquest. This also prevents us from assessing the effect of externalities - for instance, whether the confederation encompassed the entirety of the region or left out the individuals who existed outside of Iga's warrior family structure.
} 
region's culture, which created a strong homogeneous identity among the ninjas (Turnbull, 2014: 15). Such social closeness augments the mechanisms of "enforcement to ensure cooperation" almost to the point at which compliance becomes automatic (Leeson, 2007a, 2007b: 161-62).

Of particular interest is article 11 of the Iga constitution, which calls for a meeting with Kōka. This means that the ninja heartland realized that cooperation would bring significant benefits. By stopping their constant, centuries-long feuding, Iga and Kōka could reap the large benefits of moving to the highly lucrative mercenary market. The Shoninki manuscript on the ninja arts reports that the agreement of Ichi Gun Ichi Mi ("one district and one band") concluded between Iga and Kōka, and it included a written oath: "If I come to where you are, you should show me everything of your province, and if you come to where I am, I will show you everything about my province." (Cummins \& Minami, 2017: 47). The ninjas also frequently assembled at the border between their regions to discuss issues of governance and cooperation in field meetings.

Historians note that a similar constitutional arrangement to Iga's was also devised for Kōka, but on a smaller scale. The warrior families joined an agreement to form what Yūki (1988: 117) describes as an independent "republic," which functioned similarly to Iga's $i k k i$. However, little evidence survives beyond these mentions.

The historical evidence indicates the ninja succeeded in securing peace and cooperation in the territories of their ikki. This allowed them to take advantage of the thicker market, particularly the mercenary market.

\section{Concluding remarks}

The ninja confederations lasted for a century but were ultimately conquered by Oda Nobunaga and his son Nobukatsu after a series of attacks in 1579 and 1581. The invasion force of twelve thousand men, commanded by Nobukatsu in 1579, was repelled by the ninjas, but a much larger army commanded by Nobunaga in 1581 finally subjugated the confederacies. Kōka surrendered to the conqueror, while Iga was devastated when Nobunaga's men burned down most of its temples, villages, and forts (Yokoyama, 2006a, 2006b).

However, at least some of the ninjas managed to survive and even prosper after the unification of Japan, supported by the ties they had established during their shift to a thick mercenary market. Ninjas from Iga and Kōka were frequently employed by the future shogun, Tokugawa Ieyasu, during his campaigns in the Sengoku period. The ninjas also assisted him after the destruction of Iga, helping Ieyasu retreat through the mountains and back to his stronghold, after intense pursuit by his enemies. The success of the ninjas led Ieyasu to hire some of them as his honor guard and intelligence gatherers in his stronghold of Edo, even after the ninja heartland's subjugation (Zoughari, 2010: 58-59).

Yet none of this would have been possible without the private institutions that enabled the ninjas to move to a higher trade equilibrium under anarchy and made them renowned enough to warrant attention from Ieyasu himself. Eventually, the historical traditions of the ninja began to fade away during the peaceful times of the 
Tokugawa shogunate. By the second half of the seventeenth century, the ninja discipline was no longer practiced in the way that it had been during the Sengoku period. The imagery of the ninjas we see today is largely a product of fiction and marketing.

There remain some other productive areas of study regarding Sengoku Japan. For instance, a comparative analysis of constitutions of the various ikki and their relative effectiveness might be warranted, provided that the relevant historical documents may be found (Souyri, 2010: 116-17). Furthermore, ikki governance might be related to the warrior monks of Japan. A case can be made for analyzing the role that the warrior monks' religious beliefs may have played in augmenting their constitutional arrangements (Tsang, 2010).

\section{Appendix 1}

The Ninjas' Foundation Document: The Constitution of Iga's "Self-Governing League" (Man, 2013: 87-89) ${ }^{5}$ :

1. When any other domain's army intrudes on our province, the collective of the Sokoku should fight to defend against them together, with each other, as one.

2. Upon the alert sent from the gateway when the enemy are spotted, all the bells in every village should be struck and everyone should take up a position immediately. Everyone should prepare himself with food, weapons and shields and set up an encampment so as not to allow the enemy to enter the gateways of our realm.

3. All people of the ages 17 to 50 should be stationed for war. If a battle is a prolonged one, and they have to be stationed for a long period, they should rotate on a system. In every village and every area commanders should be appointed so all the men in the Sokoku can follow the orders of those said commanders. As for the temples in the Sokoku, the elders should carry out a devotional service for the prosperity of our province, while the young should take part in the camp.

4. All the hikan [lower-order people] of the Sokoku should write a solemn oath, stating that they will follow their lord whatever be the situation of our land.

5. The ashigaru [common soldiers] of our land may even capture a castle of another domain. Therefore, those who serve as ashigaru during a siege and go beyond the borders and attack a castle in another land and succeed in capturing it should be rewarded liberally for their loyalty and promoted to samurai. ${ }^{6}$

\footnotetext{
5 There are a couple of difficulties with the text. It lacks signatures and a concrete year, which indicate that the document could be a draft. However, Man (2013: 86) remains optimistic in that the document could be a "refined version of something that had been in effect for decades." The lack of other evidence of constitutional documents of the ninja may be attributed to the almost complete destruction of Iga during Oda Nobunaga's conquest of the region in 1581.

6 According to Soyuri (2010: 114), becoming a samurai within a self-governing league was largely symbolic; however, some benefits of this promotion were possibly connected to reduction in contribution payments to the league.
} 
6. If anyone intentionally lets an army of another domain in, the combined Sokoku will subjugate him and his clan and annihilate them without leaving any trace, and the land will be given over to a temple or shrine. Similarly, anyone who communicates with the enemy secretly and gives them any inside information about our land will be treated just the same as those who let the enemy army in. If someone brings information of anyone's treason in the above manner, he will be highly valued.

7. No samurai or ashigaru of our land should serve the Miyoshi clan.

8. If someone refuses to pay the Yumiya Hanjo $\operatorname{tax}^{7}$ [a "bow-and-arrow signed document" tax, presumably a war fund], he, his father, sons or brothers will not be eligible to benefit from the fund for 10 years. Neither should they be allowed to use the Yado Okuri or Mukae transportation system [a system of relay stations].

9. When positioned in a village or camp, any disorderly behavior or violence should be prohibited within the borders of our alliance.

10. As the Yamato province has unjustly attacked our province over a prolonged period of time, we should not employ any ronin [samurai unattached to a lord] who once served in the Yamato military.

11. As we have controlled our province without any problems, it is of utmost importance for us to obtain cooperation from Koga. Thus, we should have a meeting with Koga at the border between Iga and Koga at an early date.

The above commandment should be in effect with the signatures [of all who are concerned].

Acknowledgements I am grateful to Alicia Plemmons and an anonymous reviewer for their insightful comments. Natasha Purser and Harry David are credited with helping me edit the paper. I also thank the journal editor for their assistance and a generous deadline for revisions.

Authors' contribution All authors: (1) made substantial contributions to the conception or design of the work; or the acquisition, analysis, or interpretation of data; or the creation of new software used in the work; (2) drafted the work or revised it critically for important intellectual content; (3) approved the version to be published; and (4) agree to be accountable for all aspects of the work in ensuring that questions related to the accuracy or integrity of any part of the work are appropriately investigated and resolved.

Funding Not applicable.

Availability of data and material All data and materials support their published claims and comply with field standards.

Code availability Not applicable.

\section{Declarations}

Conflict of interest Not applicable.

\footnotetext{
7 The word "tax" in this case is an unfortunate translation. Since the $i k k i$ were voluntary organizations, perhaps a better term would be a "contribution.".
} 
Open Access This article is licensed under a Creative Commons Attribution 4.0 International License, which permits use, sharing, adaptation, distribution and reproduction in any medium or format, as long as you give appropriate credit to the original author(s) and the source, provide a link to the Creative Commons licence, and indicate if changes were made. The images or other third party material in this article are included in the article's Creative Commons licence, unless indicated otherwise in a credit line to the material. If material is not included in the article's Creative Commons licence and your intended use is not permitted by statutory regulation or exceeds the permitted use, you will need to obtain permission directly from the copyright holder. To view a copy of this licence, visit http://creativecommons.org/licen ses/by/4.0/.

\section{References}

Adolphson, M., \& Ramseyer, M. J. (2009). The competitive enforcement of property rights in medieval Japan: The role of temples and monasteries. Journal of Economic Behavior \&amp; Organization, 71, 660-668. https://doi.org/10.1016/j.jebo.2009.02.016

Birt, M. (1985). Samurai in passage: The transformation of the sixteenth-century Kanto. The Journal of Japanese Studies, 11(2), 369-399.

Buchanan, J. (1972). Before public choice. In G. Tullock (Ed.), Explorations in the theory of anarchy (pp. 27-37). Center for Study of Public Choice.

Buchanan, J. M. (1975). The limits of liberty: Between anarchy and leviathan. University of Chicago Press.

Buchanan, J. M., \& Tullock, G. (1962). The calculus of consent: Logical foundations of constitutional democracy. University of Michigan Press.

Cummins, A., \& Minami, Y. (2017). True path of the Ninja: The definitive translation of the Shoninki. Tuttle Publishing.

Elisonas, J. S. A., \& Lamers, J. P.(Trans. and eds.) (2011). The Chronicle of Lord Nobunaga by Ota Gyüichi. Koninklijke Brill.

Ferejohn, J. A., \& Rosenbluth, F. M. (2010). War and state building in Medieval Japan. In J. A. Ferejohn, F. M. Rosenbluth (Eds.), War and State Building in Medieval Japan (pp. 1-21). Stanford University Press.

Friedman, D. (1989). The machinery of freedom. Open Court Publishing.

Fujiki, H. (2005). Zōhyōtachi no senjō: chūsei no yōhei to dorei kari. Asahi Shinbun.

Greif, A. (2005). Institutions and the path to the modern economy: Lessons from medieval trade. In C. Menard \& M. Shirley (Eds.), Handbook of new institutional economics (pp. 727-786). Springer.

Gunning, J. P. (1972). Towards a theory of the evolution of government. In G. Tullock (Ed.), Explorations in the theory of anarchy (pp. 19-26). Center for Study of Public Choice.

Leeson, P. T. (2007a). Efficient anarchy. Public Choice, 130(1-2), 41-53. https://doi.org/10.1007/ s11127-006-9071-7

Leeson, P. T. (2007b). Trading with bandits. The Journal of Law and Economics, 50(2), 303-321. https:// doi.org/10.1086/511320

Leeson, P. T. (2009). The calculus of piratical consent: The myth of the myth of social contract. Public Choice, 139, 443-459. https://doi.org/10.1007/s11127-009-9403-5

Leeson, P. T. (2011). Government, clubs, and constitutions. Journal of Economic Behavior \&amp; Organization, 80(2), 301-308. https://doi.org/10.1016/j.jebo.2011.05.006

Leeson, P. T. (2014). Anarchy unbound: Why self-governance works better than you think. Cambridge University Press.

Man, J. (2013). Ninja 1000 years of the shadow warrior. William Morrow and Company Publishing.

McGuire, M. C., \& Olson, M. (1996). The economics of autocracy and majority rule: The invisible hand and the use of force. Journal of Economic Literature, 34(1), 72-96.

Miura, J. (1966). Hojo godai-ki. Jinbutsu Oraisha.

Moselle, B., \& Polak, B. (2001). A model of a predatory state. The Journal of Law, Economics, and Organization, 17(1), 1-33. https://doi.org/10.1093/jleo/17.1.1

Powell, B., \& Coyne, C. (2003). Do pessimistic assumptions about human behavior justify government? Journal of Libertarian Studies, 17(4), 17-37.

Souyiri, P. (2010). Autonomy and war in the sixteenth-century iga region and the birth of the Ninja phenomenon. In J. A. Ferejohn \& F. M. Rosenbluth (Eds.), War and state building in medieval Japan (pp. 110-123). Stanford University Press. 
Sugiyama, H. (1974). Sengoku Daimyo. Chūō Kōronsha.

Sugiyama, H. (1980). Nihon No Rekishi, Vol. 11. Shōgakukan.

Tiebout, C. M. (1956). A pure theory of local expenditures. Journal of Political Economy, 64, 416-424.

Tobe, S. (1996). Ninja to ninjutsu. Mainichi Shinbunsha.

Tsang, C. R. (2010). "Advance and be reborn in paradise ...": Religious opposition to political consolidation in sixteenth-century Japan. In J. A. Ferejohn \& F. M. Rosenbluth (Eds.), War and state building in medieval Japan (pp. 91-110). Stanford University Press.

Turnbull, S. (2014). The Ninja: An invented tradition? Journal of Global Initiatives: Policy, Pedagogy, Perspective, 9(1), 9-26.

Turnbull, S. (2017). Ninja: Unmasking the myth. Casemate Publishers.

Yamaguchi, M. (1962). Ninja no Seikatsu. Ozan kyakan.

Yokoyama, T. (2006a). Iga Tenshō no ran. Shinpu Shobō.

Yokoyama, T. (2006b). Nobunaga to Ise. Iga-Mie Sengoku monogatari. Sōgensha.

Yūki, S. (1988). Kōka jōkaku gun. Rekishi Dokuhon, 482, 114-121.

Zoughari, K. (2010). The ninja: ancient shadow warriors of Japan. Tuttle Publishing.

Publisher's Note Springer Nature remains neutral with regard to jurisdictional claims in published maps and institutional affiliations. 